\title{
EXPLORING THE BENEFITS AND Pitfalls of Using Mutual WILLS
}

\author{
JULIE CASSIDY
}

[The purpose of this article is to consider a peculiar type of will known in equity as a mutual will. The major focus is a consideration of the interplay of the legal effect of mutual wills and the practical use of such wills. It is hoped that this discussion will assist legal practitioners in identifying those clients who may benefit from executing mutual wills, identifying those clients who might intend to execute mutual wills, advising clients as to the pros and cons of mutual wills and the benefits of accompanying such wills with a deed or contract.]

\section{INTRODUCTION}

The purpose of this article is to consider a peculiar type of will known in equity as a mutual will and, in particular, to explore the benefits and pitfalls of using such wills. It appears from the author's research that while some legal practitioner's often draft mutual wills, others avoid advising clients to use such wills for fear of their uncertain legal effect. This article is particularly directed at the latter group of practitioners and will hopefully place them in a more informed position when deciding whether to advise their clients as to the suitability of mutual wills. Solicitors that have experience in drafting mutual wills will also be assisted by the discussion of factors that might indicate that a client intends their wills to be mutual wills and the checklist of factors detailed at the end of the article that should be considered when drafting any side agreement/deed to accompany the mutual will. Furthermore, the relevance of the discussion of topics such as severing joint tenancies and testator family maintenance legislation is not confined to the context of mutual wills and are matters that all legal practitioners working in the area of wills and succession need to be mindful.

To appreciate the benefits and pitfalls of mutual wills it is necessary to begin with a basic understanding of the legal effect of such wills. While this has been explored in detail in the text by the author MUTUAL WiLLS (2000), the most crucial attribute

\footnotetext{
* Paper presented at the Wills, Succession \& Estate Planning Conference, Melbourne, Victoria, 15 March 2005.

* Associate Professor, School of Law, Deakin University.
} 
of mutual wills is their legally binding nature. A party to a mutual wills agreement is bound not to revoke his/her will in their lifetime without notifying the other party and thereby giving the other party the opportunity to revoke their own will. ${ }^{1}$ Moreover, once one party to the mutual wills agreement dies leaving his or her will unrevoked, equity intervenes and treats the agreement as irrevocable. ${ }^{2}$

As mutual wills are binding, the key purpose of such wills is to ensure that property flows to intended, agreed, beneficiaries. They are generally used to ensure that a testator's property can be enjoyed by another during his or her lifetime, but then passes to a third party, the 'ultimate beneficiary.' They may also be used to ensure that a testator's interest in jointly owned property passes to a third party beneficiary, not the other joint owner. Who may benefit from mutual wills is discussed below. Moreover, some of the issues pertaining to joint property, such as severing joint tenancies, are discussed in more detail below.

In effecting these purposes, equity is concerned with preventing fraud. ${ }^{3}$ Disputes pertaining to mutual wills fall "[u]nder the equitable jurisdiction for the prevention of fraud". 4 The fraud has been expressed by some courts as the survivor, the second testator, taking the benefit under the first testator's will and the second testator then abrogating the trust embodied in his or her own will by revoking that will. ${ }^{5}$ The second testator acts fraudulently if he/she attempts to take the benefit under the first testator's will without the burden attaching to it. Alternatively, and preferably, the fraud is the second testator allowing the first testator to die in the belief that the second testator would comply with the terms of the agreement and the second testator then subsequently disposes of his or her property other than in accordance

\footnotetext{
${ }^{1}$ Bigg v. Queensland Trustees Ltd., [1990] 2 Qd R 11, 15 (Supreme Court of Queensland, 1989).

2 Chamberlaine v. Chamberlaine, (1680) 22 ER 1053 (Eng. Chancery Division of the High Court, 1680); Dufour v. Pereira, (1769) 21 ER 332, 333; 1 Dick 419, 420; 2 Harg Jurid Arg 304, 308 and 310 (Eng. Chancery Division of the High Court, 1769); Lord Walpole v. Lord Orford, (1797) 3 Ves 402; Ch 38; (1799) 2 Harg Jurid Arg, 292 and 294-295 (Eng Chancery Division of the High Court, 1797); Birmingham v. Renfrew, (1937) 57 CLR 666, 682, 683 and 685-689 (High Court of Australia, 1937); Re Cleaver, [1981] 1 WLR 939, 947 (Eng C.A.1981); Bigg v. Queensland Trustees Ltd., [1990] 2 Qd R 11, 13 and 16; Proctor v. Dale, [1994] Ch 31, 42 and 48; [1993] 3 WLR 652, 659-660 and 665 (Eng. Chancery Division of the High Court, 1993); Re Goodchild, [1996] 1 WLR 694, 698-699, 700 and 702 (Eng. Chancery Division of the High Court, 1996).

${ }^{3}$ Chamberlaine v. Chamberlaine, (1680) 22 ER 1053; Dufour v. Pereira, (1769) 21 ER 332; 1 Dick 419; 2 Harg Jurid Arg 304, 307 and 310; Lord Walpole v. Lord Orford, (1797) 3 Ves 402; Ch 38; (1799) 2 Harg Jurid Arg, 294-295; Birmingham v. Renfrew, (1937) 57 CLR 666, 683, 685, 688 and 689; Bigg v. Queensland Trustees Ltd., [1990] 2 Qd R 11, 13; Proctor v. Dale, [1994] Ch 31, 42, 48 and 49; [1993] 3 WLR 652, 659-660, 665 and 666.

${ }^{4}$ Dixon J in Birmingham v. Renfrew, (1937) 57 CLR 666, 688 quotes McCormick v. Grogan, (1869) LR 4 HL 82, 97 (Eng. H.L. 1869) to the effect that "the jurisdiction which is invoked here by the appellant is founded altogether on personal fraud. It is a jurisdiction by which a Court of Equity, proceeding on the ground of fraud, converts the party who has committed it into a trustee for the party who is injured by that fraud".

5 Dufour v. Pereira, (1769) 21 ER 332, 333; 2 Harg Jurid Arg 304, 311; Stone v. Hoskins, [1905] P 194, 197 (Eng. Probate Division, 1905); Re Hagger, [1930] 2 Ch 190, 195 (Eng. Chancery Division of the High Court, 1930); Birmingham v. Renfrew, (1937) 57 CLR 666, 683; Clausen v. Denson, [1958] NZLR 572, 579 (Supreme Court of New Zealand, 1958); Re Cleaver, [1981] 1 WLR 939, 947; Low v. Perpetual Trustees WA Ltd., (1995) 14 WAR 35 (Supreme Court of Western Australia, 1995).
} 
with the agreement. ${ }^{6}$ Under this view, the second testator does not have to benefit under the first testator's will. ${ }^{7}$ The crucial element is that the first testator has acted to his or her detriment by exercising the power of testamentary disposition in the agreed manner and as a consequence the second testator should not act contrary to the mutual wills agreement.

\section{Who WiLl Benefit from Executing Mutual Wills?}

There will be a number of circumstances when testators will be particularly concerned to ensure that their property passes in the manner they intend. The most common category is persons whom remarry and have children from a previous marriage. In such circumstances they may wish to make provision for their new spouse, but also intend their property to ultimately flow to the children of the first marriage. They might therefore decide that they wish their new spouse to enjoy the testator's property or his/her interest in joint property during the new spouse's lifetime. It will be seen this may be affected through a life tenancy or the conferral of an absolute interest on the surviving spouse. Equally, though the testator may wish that his/her property pass to his/her children once the new spouse dies. Subject to the surviving spouse not breaching the mutual wills agreement, discussed in more detail below, mutual wills can be used to ensure that the testator's children from the previous marriage are the ultimate beneficiaries of such property.

Alternatively, the testator may simply wish that his/her estate pass to the testator's children from the previous marriage without conferring any interest on the new spouse. Mutual wills will be particularly relevant in such circumstances when property is jointly owned. Thus in Smeaton v. Pattison, ${ }^{8}$ a non-mutual wills case, the testator wished for his interest in jointly owned property to pass to his children, rather than his new wife. 9 The solicitor drafting the will was held to be liable to the children as a failure to sever the joint tenancy meant that the property devolved to the new wife. ${ }^{10}$ Mutual wills can ensure property passes in the intended manner, rather than passing to the joint owner through the law of survivorship. While it is suggested below that in such a situation it is best practice to sever the joint tenancy in the testator's lifetime, the effect of the mutual wills is to sever any joint tenancy,

\footnotetext{
${ }^{6}$ Dufour v. Pereira, (1769) 21 ER 332, 333; 1 Dick 419, 421; 2 Harg Jurid Arg 304, 308 and 310-311; Chamberlaine v. Chamberlaine, (1680) 22 ER 1053; Lord Walpole v. Lord Orford (1797) 3 Ves 402; Ch 38; (1799) 2 Harg Jurid Arg 292 and 294-295; Re Hagger, [1930] 2 Ch 190, 195; Birmingham v. Renfrew, (1937) 57 CLR 666, 682-683 and 685-689; Bigg v. Queensland Trustees Ltd., [1990] 2 Qd R 11, 13 and 16; Proctor v. Dale, [1994] Ch 31, 42 and 48; [1993] 3 WLR 652, 659-660 and 665.

7 The courts have held that it is not a prerequisite of the mutual wills doctrine that the second testator benefit under the first testator's will. See Re Hagger, [1930] 2 Ch 190, 195; Swain v. Mewburn (unreported, WASC, No 36 of 1993, 17 February 1994) (Supreme Court of Western Australia, 1994), 11; Proctor v. Dale, [1994] Ch 31, 38 and 42, 48 and 49; [1993] 3 WLR 652, 656, 659-660, 665 and 666; Osborne v. Osborne, [2001] VSCA 228, paras 24-25 (Victorian Court of Appeal, 2001).

${ }^{8}$ [2002] QSC 431; [2003] QCA 341.

9 [2002] QSC 431, paras 3 and 27; [2003] QCA 341 para 5.

${ }^{10}$ [2002] QSC 431, para 39; [2003] QCA 341.
} 
creating a tenancy in common, ${ }^{11}$ and the second testator holds, inter alia, the first testator's property on trust for the beneficiaries of the mutual wills. ${ }^{12}$

Blended families are not the only clients who may benefit from mutual wills. A testator may simply wish that their estate pass to a particular beneficiary, rather than their spouse or a joint tenant. Thus in Osborne v. Osborne ${ }^{13}$ the testator and testatrix were concerned that their property pass to their two sons, rather than each other. ${ }^{14}$ While the courts ultimately held the subject wills were not mutual wills because there was no clear contract / agreement not to revoke the wills, ${ }^{15}$ the case provides an example of the variety of concerns that might be promulgated through mutual wills. Similarly in Carr-Glynn v. Frearsons, ${ }^{16}$ again a case not involving mutual wills, the testatrix wished to bequeath to her niece property that the testatrix held with her nephew as joint tenants. The solicitor drafting the will was held liable to the niece because the failure to sever the joint tenancy meant that the property devolved to the joint tenant rather than as the testatrix had instructed. While again it is suggested below that in such a situation the joint tenancy should have been severed in the testator's lifetime, as noted above, the effect of the mutual wills is to sever any joint tenancy, creating a tenancy in common. ${ }^{17}$ Thus mutual wills may be used to ensure an interest in joint property devolves in the manner intended by the testator/testatrix.

A person who is in a relationship which is not recognised in law as constituting a marriage may be particularly concerned that their partner is provided for when they die. Laws governing the devolution of property on the death of one party to a legally recognised marriage may be inapplicable to, for example, gay couples. Such couples may, therefore, be concerned to ensure that their property devolves to their partner under the terms of a will, rather than to other family members under intestacy laws.

As the decision in Barns v. Barns ${ }^{18}$ indicates, mutual wills may also be used in a bid to avoid testator family maintenance legislation. While in that case a majority of the

\footnotetext{
11 In re Wilford's Estate, (1879) 11 Ch D 267, 269 (Eng. Chancery Division of the High Court, 1879); Re Heys, [1914] P 192, 194 and 195-

196 (Eng. Probate Division, 1914); Gould v. Kemp, (1834) 2 My \& K 304, 309 and 310; ER 959, 961 and 962 (Eng. C.A. 1834); Re Hagger, [1930] 2 Ch 190, 195; Re Kerr, [1948] 3 DLR 668, 678 (Ontario High Court, 1948); Clausen v. Denson, [1958] NZLR 572, 579; Szabo v. Boros, (1966) 60 DLR (2d) 186, 189-190 (British Columbia Supreme Court, 1966); (1967) 64 DLR (2d) 48, 49-50 and 52-53 (British Columbia Court of Appeal, 1967); Re Gillespie, [1968] 3 DLR (3d) 317, 321 and 322 (Ontario Court of Appeal, 1968).

${ }^{12}$ [1930] 2 Ch 190, 195.

13 [2000] VSC 95; [2001] VSCA 228, paras 24-25.

${ }_{14}$ [2000] VSC 95, paras 3-6 and 23.

15 [2000] VSC 95, paras 20, 21 and 22; [2001] VSCA 228, paras 11, 14 and 15.

16 [1999] Ch 326. See also Schofield v. Watts, unreported, 5 October 1999, (District Court of Queensland, 1999).

${ }^{17}$ In re Wilford's Estate, (1879) 11 Ch D 267, 269; Re Heys, [1914] P 192, 194 and 195-196; Gould v. Kemp, (1834) 2 My \& K 304, 309 and 310; ER 959, 961 and 962; Re Hagger, [1930] 2 Ch 190, 195; Re Kerr, [1948] 3 DLR 668, 678; Clausen v. Denson, [1958] NZLR 572, 579; Szabo v. Boros, (1966) 60 DLR (2d) 186, 189-190; (1967) 64 DLR (2d) 48, 49-50 and 52-53; Re Gillespie, [1968] 3 DLR (3d) 317, 321 and 322 .

${ }^{18}$ [2003] HCA 9 (High Court of Australia, 2003).
} 
High Court held that the subject mutual wills and deed did not have the effect of preventing the application of the Inheritance (Family Provisions) Act, 1972 (SA), mutual wills continue to have a role in this context despite the decision. It is contended below that the decision is erroneous and is based on a misconception of the legal effect of mutual wills. Moreover, such legislation has its limitations and inter vivos arrangements are still effective to avoid the legislation unless the particular Act expressly extends to such transactions. As discussed below, mutual wills can be combined with inter vivos transfers of property and thus can still limit the application of testator family maintenance legislation.

\section{IDENTIFYING Clients Who INTEND THEIR WILLS to Operate as Mutual Wills}

Solicitors who are instructed to draft wills must be open to the notion that his/her client might be intending their wills to operate as mutual wills. There are undoubtedly going to be cases where clients will seek to ensure their property devolves according to the terms of what is known in equity as mutual wills, without expressly conveying such to their solicitor. This will of course lead to problems on the death of either or both testator/testatrix if the wills are challenged in the courts on the basis that they are not mutual wills. A failure to draft the wills with a clear statement that they are intended to be irrevocable and/or a failure to sever any joint tenancies may in turn leave a solicitor open to claims of negligence. It is now well established that solicitors drafting wills owe a duty of care, not only to the client, but the intended beneficiaries. ${ }^{19}$ As noted above, in, inter alia, Smeaton v. Patti$\operatorname{son}^{20}$ and Carr-Glynn v. Frearsons ${ }^{21}$ the solicitors drafting the subject wills were held to be liable to the intended beneficiaries when failing to sever the joint tenancy meant that instead the property devolved to the joint tenant. The courts have held that such a claim may be made brought by the deceased estate or the disappointed beneficiary. ${ }^{22}$ There is no reason why a failure to draft an effective mutual will will not also attract such liability.

Moreover, equally relevant in the context of mutual wills is the general principle that a practitioner's duty includes providing reasonable assistance with the signing and attestation of the will. Particularly in the context of mutual wills, it is important to ensure that wills are properly attested. The solicitor should not simply draft the wills and send them to the clients for attesting. In Esterhuizen v. Allied Dunbar

\footnotetext{
19 Hill v Van Erp, (1997) 188 CLR 159 (High Court of Australia, 1997); Schofield v. Watts, unreported decision of District Court of Queensland, 5 October 1999; Smeaton v. Pattison [2002] QSC 431 (Supreme Court of Queensland, 2002); [2003] QCA 341 (Queensland Court of Appeal, 2003). See also in the English context: White v. Jones, [1995] 2 AC 207 House of Lords, 1995); Carr-Glynn v. Frearsons, [1999] Ch 326 (Eng. C.A. 1999).

${ }_{20}$ [2002] QSC 431; [2003] QCA 341. See also Schofield v. Watts, unreported decision of District Court of Queensland, 5 October 1999.

${ }^{21}$ [1999] Ch 326.

${ }^{22}$ See again Hill v Van Erp, (1997) 188 CLR 159; Carr-Glynn v. Frearsons, [1999] Ch 326; Schofield v. Watts, unreported decision of District Court of Queensland, 5 October 1999; Smeaton v. Pattison, [2002] QSC 431; [2003] QCA 341.
} 
Assurance $P L C^{23}$ Longmore $\mathrm{J}$ asserted that it is "not enough just to leave written instructions with the testator. In ordinary circumstances just to leave written instructions and to do no more not only would be contrary to good practice but also in my view negligent." Rather, precedent provides that the solicitor should ensure the client attests the document(s) in the solicitor's office or the solicitor should attend the client's home to ensure the document(s) is properly attested. These sentiments are applicable to the wills themselves and any related documentation, such as that pertaining to a severance of joint tenancy or deed.

Given the importance of identifying clients that intend to execute mutual wills, there are a number of factors that legal practitioners should be mindful of, alerting them that their client might intend to execute mutual wills. At the most general level, the mere fact a client has consulted the solicitor to prepare a will and, in particular, to revoke a former will and execute a new will should alert the practitioner that the client has a serious issue of concern. Smeaton v. Pattison ${ }^{24}$ is instructive in this regard, the court placing great weight on the fact the client contacted the solicitor with the express intention of executing a new will. This indicated to the court the importance the client placed on ensuring his property devolved in the manner he intended. ${ }^{25}$ This was also held to be important in Carr-Glynn v. Frearsons. ${ }^{26}$ Such sentiments are particularly applicable in the context of mutual wills.

The terms of instructions may also indicate the client intends to execute a mutual will. Particularly in the context of a married couple, if the instructions indicate that property is to devolve otherwise than absolutely to the surviving spouse this may be indicative of a wish to execute mutual wills. If, as in Osborne v. Osborne ${ }^{27}$ and Proctor v. Dale, ${ }^{28}$ the testator and testatrix bequeath their property to their children, rather than each other, then this may evidence a wish to execute mutual wills and the solicitor should make further inquiries into the parties' wishes. Irregardless of whether the wills are intended to be mutual wills, in this context it will again be important to sever any joint tenancy to ensure that the testator's wishes are effective and the property devolves to the intended beneficiaries, rather than through the law of survivorship. Equally if, as in Dufour v. Pereira, ${ }^{29}$ Re Hagger $^{30}$ and Swain v. Mewburn, ${ }^{31}$ the testator and testatrix bequeath only a life tenancy to the survivor and then to, for example, one party's children or relatives, this will be indicative of a wish to execute mutual wills and the solicitor should again make further inquiries into the parties' wishes.

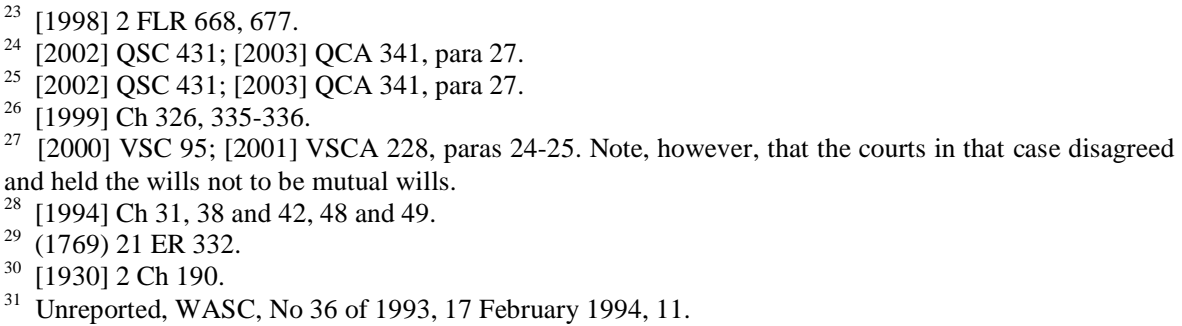


The corollary, however, is that mutual wills are less likely to be intended when an absolute interest is conferred on the surviving spouse. As Oldham $\mathrm{J}$ explained in $R e$ Oldham $^{32}$ :

Of course it is a strong thing that these two parties came together, agreed to make their wills in identical terms and in fact so made them. But that does not go nearly enough. If the spouses intended to do what the plaintiff suggests, it is difficult to see why the mutual wills gave the survivor an absolute interest in the whole of the property of the one who died first ... Could these parties have acted as they did with any other object or intent than the plaintiff asserts? It is impossible to deny that they could.

Consequently, the court held the wills were not mutual wills because they conferred an absolute interest upon the second testator and that was inconsistent with the obligations imposed under mutual wills. ${ }^{33}$

That is not to say that mutual wills cannot confer an absolute interest on the surviving spouse. The wills in Birmingham v. Renfrew ${ }^{34}$ conferred an absolute interest on the surviving spouse. In such cases care will be needed to ensure that some other factor, such as a blended family, indicates an intention for mutual wills. As there is a strong presumption in such a case that the wills were not intended as mutual wills, ${ }^{35}$ any intention to execute mutual wills must be made clear in the wills and any accompanying contract or deed.

The nature of the property, particularly the devolution of jointly owned property to a person other than the other joint owner, may also indicate an intention to execute mutual wills. In regard to jointly owned property there are two further related points that must be borne in mind. First, the solicitor drafting a will has a duty to determine if any of the testator's property is jointly held so that, where necessary, any joint tenancy can be severed. There will of course be cases where the solicitor knows the legal status of the testator's property because he/she or their firm may have acted for the client in the relevant conveyance. ${ }^{36}$ However, in the absence of such knowledge it is important for the solicitor preparing the will to determine if property is held as joint tenants or tenants in common. Legal practitioners cannot expect a layperson, who may not understand the difference in the nature of the title much less its legal significance, to advise them as to the nature of the ownership of property.

Second, where the mutual wills agreement involves joint property devolving to a third party beneficiary the solicitor should ensure any joint tenancy is severed. There are two reasons for this. While the better view is that equity will sever the

\footnotetext{
32 Re Oldham, [1925] 1 Ch 75, 87-88 (Eng. Chancery Division of the High Court, 1924). See also Birmingham v. Renfrew, (1937) 57 CLR 666, 674; Osborne v. Osborne, [2001] VSCA 228, para 28; Baird v. Smee, [2000] NSWCA 253, paras 8 and 10 (New South Wales Court of Appeal, 2000).

${ }^{33}$ [1925] 1 Ch 75, 87.

34 Birmingham v. Renfrew, (1937) 57 CLR 666.

35 Re Oldham, [1925] 1 Ch 75, 87-88. See also Birmingham v. Renfrew, (1937) 57 CLR 666, 674; Osborne v. Osborne, [2001] VSCA 228, para 28; Baird v. Smee, [2000] NSWCA 253, paras 8 and 10.

${ }^{36}$ As in Carr-Glynn v. Frearsons, [1999] Ch 326, 331.
} 
joint tenancy in the case of mutual wills, ${ }^{37}$ the Australian courts have not determined the matter. It is also unclear from the Canadian and English cases whether there is a severance in both law and equity. If the severance is only in equity, legal title will pass to the survivor under the law of survivorship, but equity will impose a trust in favour of the beneficiaries under the mutual wills agreement. ${ }^{38}$ This might prove problematic if the survivor in turn decides to breach that trust. Further, if for any reason the wills are held not to be mutual wills it will be crucial that any joint tenancy has been severed because, as discussed above, the solicitor will be liable in negligence if the will he or she has drafted purports to devolve property to a person(s) other than the joint tenant where the joint tenancy has not been severed. ${ }^{39}$ In this regard it is pertinent to note that in Carr-Glynn v. Frearsons ${ }^{40}$ the court stressed that some urgency must attach to this issue when the testatrix is elderly to ensure the joint tenancy is severed before her death. In that case the testatrix was 81 years of age when she made her will. ${ }^{41}$

This last point leads to another indicia of an intention to execute mutual wills, the age of the parties. That this might be indicative is supported by the decision in Swain v. Mewburn, ${ }^{42}$ In determining in that case that the subject wills were mutual wills the court placed great emphasis on the age of the testators (in their fifties), the period of their marriage (almost 20 years) and the unlikeliness of the parties remarrying. Similarly in Baird v. Smee $e^{43}$ Mason $\mathrm{P}$ acknowledged that the "couple were at least middle-aged" might be indicative of mutual wills and that mutual wills "might be appropriate in the case of an elderly married couple wishing to settle their affairs in the same way before they die." Thus the older the client the more likely that they might be prepared to enter into a binding arrangement as the will that is being drafted is realistically intended to be their last will.

\section{Advising Clients on the Advantages AND DisADVANTAGES OF MUTUAL WILLS}

When advising clients as to the advantages and disadvantages of mutual wills and/or any accompanying contract or deed it is important that they understand that the legal arrangements are prima facie irrevocable. It may be awkward, but in the course of such discussions it is important to have the clients consider what they

\footnotetext{
37 In re Wilford's Estate, (1879) 11 Ch D 267, 269; Re Heys, [1914] P 192, 194 and 195-196; Gould v. Kemp, (1834) 2 My \& K 304, 309 and 310; ER 959, 961 and 962; Re Hagger, [1930] 2 Ch 190, 195; Re Kerr, [1948] 3 DLR 668, 678; Clausen v. Denson, [1958] NZLR 572, 579; Szabo v. Boros, (1966) 60 DLR (2d) 186, 189-190; (1967) 64 DLR (2d) 48, 49-50 and 52-53; Re Gillespie, [1968] 3 DLR (3d) 317, 321 and 322 .

38 See further Julie CASSIDY, Mutual WILLS 61-65 (2000).

39 Carr-Glynn v. Frearsons[1999] Ch 326; Schofield v. Watts, unreported decision of District Court of Queensland, 5 October 1999; Smeaton v. Pattison, [2002] QSC 431; [2003] QCA 341.

42 Unreported decision of the Full Court of the Supreme Court of Western Australia, 3 March 1994, 9 and 12 .

${ }^{43}$ [2000] NSWCA 253, paras 9 and 17.
} 
wish to happen if, for example, they divorce and/or remarry. While this will be particularly so when the clients are young enough for this to be quite realistic, as the facts in Osborne v. Osborne $e^{44}$ indicate, the possibility of remarriage is something to be mindful even when the testators are in their 70's.

The issue of irrevocability will be particularly important where the mutual wills agreement is combined with an inter vivos transfer of property. It will be seen below that to avoid testator family maintenance legislation parties might decide to make an inter vivos transfer of what would otherwise be part of the deceased's estate. The clients must understand that the transfer is irrevocable and the recipient's interest in that property is absolute in the absence of any express restrictions.

Moreover, while the mutual wills agreement or deed might seek to limit the recipient's enjoyment of the property, if this is intended the agreement must be very clear. Again Osborne v. Osborne ${ }^{45}$ is factually instructive. The plaintiff had asserted that his parents had executed mutual wills. As a consequence, it was contended that when his father gifted the family home ('the unit') to his new spouse after the death of the plaintiff's mother, his father had breached the mutual wills. As noted above, the courts held the wills not to be mutual wills and as a consequence a caveat the plaintiff placed over the subject unit for the duration of the litigation, was ordered to be removed. The new spouse, the recipient of the gifted unit, mortgaged the property on two occasions and ultimately, through the first mortgagors, sold the unit. This was so even though the gift of the unit had been conditional on her entering into a Deed of Family Arrangement and executing a will bequeathing the unit to certain members of the Osborne family. ${ }^{46}$ Subsequent to the first mortgage, in the course of refusing an application to stay the orders of the court at first instance, ${ }^{47}$ Beach $\mathbf{J}$ asserted that even life tenant, such as the new spouse, was entitled to mortgage the property. In later proceedings, brought by one of the intended beneficiaries under the Deed of Family Arrangement and the will of the new spouse, the new spouse pleaded that she was the absolute owner of the unit that had been gifted to her and that any obligations pertaining to that property under the Deed of Family Arrangement ceased when the donor, Mr Osborne, died. The proceedings against the new spouse were ultimately discontinued. Thus despite the deed the unit was mortgaged and ultimately sold by the new spouse. Thus if a life interest or an absolute interest in property is to be conveyed through an inter vivos transfer it is important to clearly draft any restrictions that apply to the property. In particular, any restrictions, such as the ability to sell or mortgage the property, must be clear.

The discussion of this case highlights the unfortunate reality that ultimately, if a surviving spouse wants to, he/she may undermine a mutual wills agreement. It is important that clients be aware of this fact. While they may trust their spouse, that person might subsequently remarry and want to make provision for their new part-

\footnotetext{
44 [2000] VSC 95, para 1. In that case the surviving spouse remarried in his late 70's and gifted the property the subject of a mutual wills claim to his new spouse subject to a Deed of Family Arrangement: [2000] VSC 95, para 8.

45 [2000] VSC 95; [2001] VSCA 228

46 [2000] VSC 95; [2001] VSCA 228, paras 24-25.

${ }^{47}$ [2001] VSC 95, para 24.
} 
ner. Family members may pressure them into breaching the agreement so that they benefit. It may be that the spouse always intended to breach the agreement.

A well-drafted contract or deed accompanying the mutual wills will lessen the chances of a breach. From a practical point of view, however, the breach needs to be discovered in time for it to be rectified. Over a period of time the surviving spouse who benefits under the will of the first to die may deliberately diminish his/her estate through systematic withdrawals of funds or gifts. Secretly mortgaging or selling property the subject of a mutual wills agreement may also be effective to dispossess the recipient of the relevant property even in the face of an iron clad agreement. As Callinan $\mathrm{J}$ warned in Barns v. Barns, ${ }^{48}$ the "fact that the surviving contracting party, who is the beneficiary under the will of the first of the two to die, may use, and indeed even ultimately use up in their entirety the assets passing under the first will, provides a reminder that in human affairs, even in legal affairs, perfection, and the complete effectuation of intention are sometimes not possible." These issues are discussed in more detail below.

\section{Recognising Potential Problems with Second MARRIAGES, BLENDED FAMILIES AND OTHER FAMILY ISSUES}

The relevance of mutual wills in blended families has already been addressed above. As, however, this context raises issues that are peculiar to their context it is pertinent to return to this factual scenario.

Today it is common for legal practitioners to have clients who have remarried and may have children from a former marriage. Blended families pose difficult issues for practitioners who may feel disinclined to ask awkward questions, but who also have to be mindful of their obligations to their clients, outlined above, and the potential liability they face from disappointed beneficiaries. For example, where a client is bequeathing their entire estate to a surviving spouse, it may be awkward, but the client should be asked whether they intend to make any provision for his/her children. It is important that the client be advised that on its own such a bequest places the surviving spouse under no legal obligation to pass that property to the first testator's children. Clients may be happy to trust their surviving spouse to act in the manner they intended. Others, however, once properly advised, may feel that they want more than a moral obligation to ensure the property devolves to their children. Thus mutual wills and, perhaps a contract or deed, discussed below, might serve such clients' wishes.

This is particularly so where a new spouse is not prepared to accept a mere life tenancy under the terms of the will of the first to die. Research indicates that today spouses are not happy to be bequeathed life tenancies in property, but rather demand the conferral of an absolute interest in bequeathed property. A life tenancy is not seen as an adequate conferral of benefit. Again, bequeathing an absolute interest in property without a legally binding restriction is risky when the first testator in

\footnotetext{
${ }^{48}$ [2003] HCA 9, para 152
} 
reality only intends the survivor to enjoy the property in his/her lifetime, with an obligation to pass property to the ultimate beneficiaries, for example, their children.

Even where the will only confers a life tenancy on the surviving spouse, the same problem may arise where there has been a failure to sever any joint tenancy. Even though the first testator's will may only confer a life interest on the surviving spouse, the property may nevertheless devolve to the surviving spouse through the law of survivorship if the joint tenancy has not been severed. Despite the terms of the will, in such a case the surviving spouse will have acquired an absolute interest in the property and only moral obligations will ensure it is bequeathed to the ultimate intended beneficiaries. Thus in Schofield $v$. Watts ${ }^{49}$ the testator had made provision in his will for his wife to be maintained for her lifetime and the residue was to pass to his brothers and sisters. However, as relevant joint tenancies were not severed the property passed to his wife absolutely, contrary to his intentions and instructions. The solicitors were held liable to the intended beneficiaries for their negligent failure to sever the joint tenancy.

Where a mutual wills agreement is entered into limiting the survivor's enjoyment of property, it is important that the ultimate beneficiaries know of the agreement. If the surviving spouse proposes to breach the mutual wills agreement, the beneficiaries may, for example, seek injunctive relief. ${ }^{50}$ If the surviving spouse makes inter vivos gifts in breach of the mutual wills agreement, ${ }^{51}$ the beneficiaries will be entitled to disgorge the volunteer of the property. ${ }^{52}$ Equally if the surviving spouse revokes his/her will and makes a testamentary disposition contrary to the mutual wills, the beneficiaries will have a claim in equity. ${ }^{53}$ They may enforce the arrangement without facing any privity hurdles as they are enforcing the trust, rather than the

\footnotetext{
${ }^{49}$ Unreported decision of District Court of Queensland, 5 October 1999. See also Osborne v. Osborne, [2000] VSC 95 para 1 (Supreme Court of Victoria, 2000) where the surviving spouse acquired the unit by survivorship despite the terms of the testatrix's will.

${ }^{50}$ Schaefer v. Schuhmann, [1972] AC 572, 586 (Privy Council, 1971).

${ }^{51}$ Gregor v. Kemp, (1722) 36 ER 926, 926 and 927 (Eng. Chancery Division of the High Court, 1722); Re Hagger [1930] 2 Ch 190, 195; Birmingham v. Renfrew, (1937) 57 CLR 666, 689 and 690; Schaefer v. Schuhmann, [1972] AC 572, 599; Re Cleaver, [1981] 1 WLR 939, 946 and 947; Nowell v. Palmer, (1993) 32 NSWLR 574, 578 (New South Wales Court of Appeal, 1993); Re Goodchild, [1996] 1 WLR 694,700 .

52 Chamberlaine v. Chamberlaine, (1680) 22 ER 1053; Gregor v. Kemp, (1722) 36 ER 926; Lord Walpole v Lord Orford, (1797) 3 Ves 402; Ch 38; (1799) 2 Harg Jurid Arg 294-295; Legard v. Hodges, (1792) 30 ER 447, 447; (1792) 1 Ves Jun 477-478 (Eng. C.A. 1792); Synge v. Synge, [1894] 1 QB 466, 470-471 (Eng. C.A. 1894); Hoeppner v. Kautz, (1908) 8 SR (NSW) 186 (Supreme Court of New South Wales, 1908); Re Syme, [1933] VLR 282 (Supreme Court of Victoria, 1933); Birmingham v. Renfrew, (1937) 57 CLR 666, 685, 687 and 688; Reynolds v. Marshall, [1952] NZLR 384; Macadam v. Wright, [1958] Ch 168, 176, 179 and 181 (Eng. C.A. 1958); Szabo v. Boros, (1967) 64 DLR (2d) 48, 53; Palmer v. Bank of NSW, [1973] 2 NSWLR 244, 248-249 (New South Wales Supreme Court, 1973); Staib v. Powell, [1979] Qd R 151 (Supreme Court of Queensland, 1979); Bigg v Queensland Trustees Ltd., [1990] 2 Qd R 11, 13.

${ }_{53}$ Gregor v. Kemp, (1722) 36 ER 926, 926 and 927; Fortescue v. Hennah, (1812) 34 ER 443, 445 (Eng C.A. 1812); Jones v. Martin (1798) 2 ER 1184, 1199-1200 (Eng. C.A. 1798); Synge v. Synge, [1894] 1 QB 466; In re Gardner, [1920] 2 Ch 523, 529 (Eng. Chancery Division of the High Court, 1920); Re Kerr, [1948] 3 DLR 668, 679; Re Green, [1951] Ch 148 (Eng. Chancery Division of the High Court); Szabo v. Boros, (1967) 64 DLR (2d) 48, 53; Schaefer v. Schuhmann, [1972] AC 572, 599; Palmer v. Bank of NSW, (1975) 133 CLR 150, 159 (High Court of Australia, 1975); Bigg v. Queensland Trustees Ltd., [1990] 2 Qd R 11, 13 and 17.
} 
agreement between the parties. ${ }^{54}$ These remedies may, however, be fruitless if the ultimate beneficiaries are not aware of the mutual wills agreement.

\section{ARE THEY EFFECTIVE POST BARNS $v$ BARNS AND “Notional Estate”" Provisions?}

A full consideration of the decision in Barns v. Barns ${ }^{55}$ is beyond the scope of this article, nevertheless some key point about the decision can be made in this context. As noted above, in Barns v. Barns ${ }^{56}$ a majority of the High Court held that the subject mutual wills and deed did not have the effect of preventing the application of the Inheritance (Family Provisions) Act, 1972 (SA). Ultimately it is submitted that despite the decision mutual wills continue to have an important role in testamentary planning.

First, and perhaps most importantly, it is contended that the decision is erroneous and is based on a misunderstanding of the legal effect of mutual wills. To this end the dissenting view of Callinan $\mathbf{J}$ is to be preferred. Callinan $\mathbf{J}$ stresses that mutual wills should not be treated differently from any other disposition / contractual obligation that would place property outside the scope of the deceased's estate and thus beyond the reach of the Inheritance (Family Provision) Act, 1972 (SA). ${ }^{57}$ This view is in turn based on a correct understanding of the timing of the effect of mutual wills. As Callinan $\mathrm{J}$ states, the obligations under the mutual wills agreement impact on the first testator, ${ }^{58}$ not only on the survivor as Gummow and Hayne JJ erroneously state. ${ }^{59}$ In support of this view it suffices to note that an actionable breach of the mutual wills agreement may occur even when both parties are alive. ${ }^{60}$ Moreover, the beneficiaries under the mutual wills derive their rights from the enforcement of the trust stemming from the agreement, rather than the second testator's will. ${ }^{61}$ Thus the mutual wills agreement is effective earlier than that suggested by the majority justices and thus impacts upon the deceased's estate in the manner suggested by Callinan J.

Also relevant to the decision's authoritative value is the fact that there is no clear majority. Gleeson $\mathrm{CJ}$, with whom Kirby $\mathbf{J}$ agreed, in essence concluded that to give

\footnotetext{
54 Dufour v. Pereira, (1769) 2 Harg Jurid Arg 304, 310-311; Hudson v. Gray, (1927) 39 CLR 473, 484 (High Court of Australia, 1927); Birmingham v. Renfrew, [1937] VLR 180, 189 (Supreme Court of Victoria, 1937); 57 CLR 666, 686 and 690 and 691-692; Staib v. Powell,[1979] Qd R 151; Re Cleaver, [1981] 1 WLR 939, 947.

${ }^{55}$ [2003] HCA 9.

56 [2003] HCA 9.

${ }^{57}$ [2003] HCA 9, paras 140, 161 and 166.

${ }^{58}$ [2003] HCA 9, paras 149, 163 and 169.

59 [2003] HCA 9, paras 82 and 84. For example, they assert that trust obligations under the mutual wills agreement do not arise until the survivor acts in an unconscionable manner. See also Gleeson CJ, para 29.

${ }^{60}$ Bigg v. Queensland Trustees Ltd., [1990] 2 Qd R 11, 17; Low v. Perpetual Trustees WA Ltd., (1995) 14 WAR 35; Synge v. Synge, [1894] 1 QB 466.

${ }_{61}$ Re Richardson's Estate, (1934) 29 Tas LR 149 (Supreme Court of Tasmania, 1934); Proctor v. Dale, [1994] Ch 31, 41; Re Goodchild, [1996] 1 WLR 694, 700.
} 
effect to the legislation's purpose, mutual wills have to be treated differently from other contractual obligations that would otherwise place the subject property outside the deceased's estate and thus the legislation's reach. ${ }^{62}$ As noted above, Gummow and Hayne JJ held that as mutual wills only impact on the survivor and the court's order under the Act operates as a codicil on the deceased's will, the mutual wills obligations were antecedent the court's determination regarding the deceased's estate. ${ }^{63}$ They also suggested that the legislation impacts on the deceased's gross, not net estate. ${ }^{64}$ As discussed below, Gleeson CJ (with who Kirby J agreed) clearly disagreed with this view. As noted above, Callinan $\mathrm{J}$ believed the mutual wills agreement effected a disposition / contractual obligation that placed property outside the scope of the deceased's estate and thus beyond the reach of the Inheritance (Family Provision) Act, 1972 (SA). ${ }^{65}$ He believed it was for the legislature, not the courts, to extend the reach of the Act to such dispositions. ${ }^{66}$ Thus in a sense the court was divided: $2: 2: 1$.

Second, the case was very much based on its facts and thus may be distinguished. Gleeson CJ, with whom Kirby J agreed, stressed that on the facts the testator and his spouse were only concerned from excluding their daughter from the estate of the survivor, not the first to die. ${ }^{67}$ If a contrary intention was established, perhaps Gleeson CJ would have held otherwise and the property could have been effectively removed from the deceased's estate.

Third, Gleeson CJ, with whom Kirby J agreed, acknowledged that the Inheritance (Family Provision) Act, 1972 (SA) has its limitations. Gleeson CJ stressed that contractual obligations and inter vivos arrangements are still effective to avoid the legislation unless the particular Act expressly extends to such transactions, as is the case under the Family Provision Act, 1982 (NSW). ${ }^{68}$ As discussed above, mutual wills can be combined with inter vivos transfers of property. However, as also warned above, care must be taken with such inter vivos transactions if it is intended that the recipient should not have full enjoyment of the property and/or be bound to bequeath the property to the ultimate beneficiaries.

Barns v. Barns ${ }^{69}$ did not consider the extended reach of the Succession Act, 1981 (Qld) or the "notional estate" provisions of the Family Provision Act, 1982 (NSW). ${ }^{70}$ These legislative enactments deal with the issue of pre-death dispositions of property in two very different ways. In Queensland the Succession Act, 1981, $\mathrm{s} 41(12)$ (Qld) provides that property the subject of a donatio mortis causa ${ }^{71}$ gift is

\footnotetext{
62 [2003] HCA 9, para 34. See also Kirby J, para 129.

63 [2003] HCA 9, paras 82, 84, 94 and 108 .

64 [2003] HCA 9, paras 105 and 106.

65 [2003] HCA 9, paras 140, 161 and 166

${ }_{66}^{60}$ [2003] HCA 9, paras 132, 159 and 171 .

67 [2003] HCA 9, paras 11, 13 and 29.

68 [2003] HCA 9, paras 5, 7, 19, 30 and 33.

69 [2003] HCA 9.

70 Although it is submitted that effectively Gummow and Hayne JJ have given the Inheritance (Family Provision) Act, 1972 (SA) the same scope as these enactments through their expansive interpretation. See [2003] HCA 9 paras $92-108$.

71 A donatio mortis causa is an inter vivos gift, but it is made in contemplation of death and conditional on the death occurring.
} 
to be treated as part of the testator's estate for the purposes of the family provision legislation.

The New South Wales legislation deals with the issue in a much broader manner by including the testator's "notional estate" in the property that may be the subject of a family provision order. ${ }^{72}$ The court has a discretion to designate property as "notional estate" where it has been the subject of a "prescribed transaction" within s 22(1) of the Act. A "prescribed transaction" occurs if through any act or omission the testator's property becomes owned by another person or subject to a trust and full valuable consideration has not been paid for the property. In addition to this general definition, the Act specifies that a number of particular acts constitute prescribed transactions. ${ }^{73}$ These include failing to prevent property passing under survivorship and the failure to extinguish a trust held over property.

If the testator has entered into a prescribed transaction the court may make an order designating property as notional estate in three circumstances: ${ }^{74}$

- if the transaction took effect within three years of the testator's death and was entered into with the object of partly or wholly preventing a person making a claim for provision;

- if the transaction took effect within one year of the testator's death and was entered into when the testator had a moral obligation to make provision for an eligible person; or

- if the transaction took effect after the testator's death.

An order designating property as notional estate may not be made unless, inter alia, there is no, or insufficient, actual estate out of which provision for the claimant may be made. ${ }^{75}$

Under s 23, in certain cases the court can make an order designating property as notional estate even if that property was not the subject of the prescribed transaction. Thus, under s 23, if the recipient of the purported gift sold the property, the court may designate other property owned by that person to be notional estate. In this way this legislation may be used by a claimant under the Family Provision Act, 1982 (NSW) to reverse attempts by the testator and / or recipients of a gift, to defeat his or her claim by making inter vivos and testamentary gifts.

This legislation certainly constrains the ability to pass property through mutual wills agreements, even when accompanied by inter vivos transactions. However, as will be apparent from the above discussion, the legislation contains temporal limits as to those transactions that may effectively be impugned. Moreover, only those entitled to apply under such legislation will have the ability to undermine through the legislation any mutual wills agreement. The issue will also not arise where the deceased has made provision for the claimant.

\footnotetext{
See Family Provision Act, 1982, ss 7 and 22 (NSW).

See Family Provision Act, 1982, s 22 (NSW).

74 See Family Provision Act, 1982, s 23 (NSW).

75 See Family Provision Act, 1982, s 28 (NSW)
} 
Perhaps most importantly, it must be recalled that disinheriting a person is not the sole reason why mutual wills are executed. As discussed above, more often the focus is upon binding the survivor to pass property to the ultimate beneficiaries. Testator family maintenance legislation does not negate the obligations mutual wills may impose on a surviving spouse to, for example, bequeath property to his/her step children.

\section{Issues Pertaining to Proving Mutual Wills}

Many issues pertaining to proving mutual wills have already been addressed above. Nevertheless, this part of the article focuses on a few key issues pertaining to proving mutual wills. From the outset it is important to note that the courts have stressed that the burden of proving mutual wills is no greater than the balance of probabilities required in all civil cases. ${ }^{76}$ There must be "clear and satisfactory" evidence that the wills were executed pursuant to an "agreement or understanding" that the property was to be "dealt with in a particular way for the benefit of a third person" ${ }^{77}$ In Re Cleaver ${ }^{78}$ Nourse J stressed that the "clear and satisfactory" test "does not mean that there has to be a departure from the ordinary standard of proof required in civil proceedings. I have to be satisfied on the balance of probabilities that the alleged agreement was made."79

Nevertheless, a number of important cautionary points regarding proving mutual wills should be noted. In an often cited passage Latham CJ stated in Birmingham v. Renfrew: ${ }^{80}$

Those who undertake to establish an agreement assume a heavy burden of proof. It is easy to allege such an agreement after the parties to it have both died, and any court should be careful in accepting the evidence of interested parties upon such a question.

Latham CJ's comment needs to be read in its context. Where, as in that case, the surviving spouse is conferred an absolute interest under the will of the first testator's, the plaintiff faces a heavy burden of proving the wills to be mutual wills. This is because, as noted above, such a bequeathing is prima facie inconsistent with an obligation to hold that property for another under an agreement for mutual wills. ${ }^{81}$

\footnotetext{
76 See also Birmingham v. Renfrew, [1937] VLR 180, 185; (1937) 57 CLR 666, 682; Low v. Perpetual Trustees WA Ltd., (1995) 14 WAR 35.

77 Re Cleaver, [1981] 1 WLR 939, 947. See also Birmingham v. Renfrew, (1937) 57 CLR 666, 681; Nowell v. Palmer, (1993) 32 NSWLR 574, 579; Low v. Perpetual Trustees WA Ltd., (1995) 14 WAR 35.

${ }^{78}$ [1981] 1 WLR 939, 947-948. This proposition was accepted by the Supreme Court of Western Australia in Low v. Perpetual Trustees WA Ltd., (1995) 14 WAR 35.

${ }^{79}$ See further Julie Cassidy, An Equitable Agreement or a Contract in Law: Merely a Matter of Nomenclature, 27 MELBOURNE U.L.REV 217, 222-227 (2003).

${ }^{80}$ (1937) 57 CLR 666, 674. See also Osborne v. Osborne, [2000] VSC 95, para 20 where Harper J asserted that it was a "heavy burden of proof."

${ }^{81}$ Re Oldham, [1925] 1 Ch 75, 87-88; Birmingham v. Renfrew, (1937) 57 CLR 666, 674. See also Buchanan J in Osborne v. Osborne, [2001] VSCA 228, para 28; Baird v. Smee, [2000] NSWCA 253, paras 8 and 10 .
} 
Nevertheless, Latham CJ's comment is a timely warning that if under the subject mutual wills agreement it is intended that the will is to confer an absolute interest on the survivor, that they are intended to be mutual wills need to be clearly spelt out in the wills and/or any contract or deed.

Another cautionary note regarding the proving of mutual wills also comes from Latham CJ's judgment in Birmingham v. Renfrew: ${ }^{82}$

The mere fact that two persons make what might be called corresponding wills in the sense that the existence of each will is naturally explained by the existence of the other will is not sufficient to establish a binding agreement not to revoke wills so made.

Again, where, as in that case, the surviving spouse had been conferred an absolute interest in the first testator's property, the simultaneous execution of the wills by the testator and testatrix is not in itself indicative of mutual wills as the conferral of an absolute interest in the property on the survivor is inconsistent with the obligations that stem from mutual wills. ${ }^{83}$ While the simultaneous execution of wills to the same effect is a relevant circumstance to proving mutual wills, ${ }^{84}$ it will be rare that such a fact might on its own support a claim for mutual wills. ${ }^{85}$ This simply reaffirms the need to make the parties' intention clear.

In regard to this last comment by Latham $\mathrm{CJ}$, it is important to note that similar comments were made in Osborne v. Osborne but in a very different factual context which might indicate the statement has a wider breadth than that suggested above. Harper J, at first instance, stated in Osborne v. Osborne ${ }^{86}$ that "many couples join in making wills which reflect their joint view of the proper disposition of their property; but in doing so they do not bind themselves not to revoke their wills or indeed to undertake or impose any other kind of obligation." On appeal, Winneke P similarly asserted "the fact of making identical wills will not, of itself, establishing an implied agreement not to revoke. This is because, as his Honour also noted, many husbands and wives make corresponding wills 'by agreement' without binding themselves not to revoke them. Such wills are infinitely more likely to be the product of mutual trust and moral responsibility than a binding obligation not to revoke." ${ }^{87}$ It will be recalled, however, that unlike in Birmingham v. Renfrew, ${ }^{88}$ in

\footnotetext{
82 (1937) 57 CLR 666, 675. Similar sentiments were expressed in Re Gillespie, (1968) 3 DLR (3d) 317, 319; Re Oldham, [1925] 1 Ch 75, 87-88; Gray Perpetual Trustee Co. Ltd., [1928] AC 391, 400 (Privy Council, 1928); Re Cleaver, [1981] 1 WLR 939, 945; Bigg v. Queensland Trustees Ltd., (1990) 2 Qd R 11, 13; Re Goodchild, [1996] 1 WLR 694, 699; [1997] 1 WLR 1216, 1224 (Eng. C.A. 1997); Osborne v. Osborne, [2000] VSC 95, para 14; [2001] VSCA 228, paras 7 and 15; Baird v. Smee, [2000] NSWCA 253, paras 30 and 71

${ }^{83}$ Re Oldham, [1925] 1 Ch 75, 87-88

84 Lord Walpole v. Lord Orford, (1797) 3 Ves 402, 418; Ch 38, 56; Re Oldham, [1925] 1 Ch 75, 87; Szabo v. Boros, (1967) 64 DLR (2d) 48, 49-50; Re Gillespie, (1968) 3 DLR (3d) 317, 319; Re Cleaver [1981] 1 WLR 939, 945; Reardon v. Mewburn (unreported, WASC, No 1217 of 1991, 26 January 1993), 18 (Supreme Court of Western Australia, 1993); Low v. Perpetual Trustees WA Ltd., (1995) 14 WAR 35.

85 See for example, Reardon v. Mewburn (unreported, WASC, No 1217 of 1991, 26 January 1993) 19; (unreported, WASC, No 36 of 1993, 17 February 1994) 14.

${ }^{86}$ [2000] VSC 95, para 21.

87 [2001] VSCA 228, para15
} 
Osborne v. Osborne ${ }^{89}$ the survivor was not conferred an absolute interest; in fact the surviving spouse was bequeathed no interest in the testatrix's estate. These statements thereby suggest that the simultaneous execution of wills by spouses, putting into effect joint intentions, will not suffice to establish mutual wills even where an absolute interest is not bequeathed to the survivor. ${ }^{90}$

Finally, there is a line of authority that suggests that a contract for mutual wills must be proved, including a contract not to revoke the wills. Thus in Osborne $v$. Osborne $e^{91}$ the court at first instance required the plaintiff to establish his claim that the subject wills were mutual wills both in contract law and equity. Harper $\mathbf{J}$ asserted that even if the plaintiff were to prove his case in equity, this would not suffice as "[p]roof of the contract is [also] a necessary ... condition." 92 The court continued: $:^{93}$

The plaintiff must prove a contract, to which each of his parents was a party, that each would make a will which, during their joint lives, would not be revoked without notice to the other; and after the death of the first to die would not be revoked by the survivor. It is true that the plaintiff sues not on a contract but upon a trust. But 'without such a definite agreement there can no more be a trust in equity than a right to damages at law'.

On appeal, the Court of Appeal quoted Baird and Anor v. Smee ${ }^{94}$ where "the Court of Appeal of New South Wales variously spoke of the "need to prove a legally binding contract' and [Aslan v. Kopf ${ }^{5}$ where the Court asserted] '... a testator may enter into a binding contract not to revoke a will ....".96 In Baird v. Smee, ${ }^{97}$ to which the Court of Appeal referred, Handley JA asserted the "need to prove a legally binding contract."

It has been suggested in earlier publications that this view is erroneous. ${ }^{98}$ It suffices to note here that there is a wealth of authority to support the view that the courts' views are erroneous as mutual wills are enforced in equity and equity merely requires, inter alia, a definite agreement, arrangement or understanding between the testators. ${ }^{99}$ Nevertheless, until the matter is authoritatively determined by the Aus-

\footnotetext{
${ }^{88}$ (1937) 57 CLR 666, 675. Similar sentiments were expressed in Re Gillespie, (1968) 3 DLR (3d) 317, 319; Re Oldham, [1925] 1 Ch 75, 87-88; Gray Perpetual Trustee Co. Ltd., [1928] AC 391, 400; Re Cleaver, [1981] 1 WLR 939, 945; Bigg v. Queensland Trustees Ltd., (1990) 2 Qd R 11, 13; Re Goodchild, [1996] 1 WLR 694, 699; [1997] 1 WLR 1216, 1224.

${ }^{89}$ [2000] VSC 95; [2001] VSCA 228.

90 Note, the author has expressed a contrary view in Cassidy, supra note 79, at 240-245.

${ }^{91}$ [2000] VSC 95, paras 20 and 35.

92 [2000] VSC 95, para 35. See also paras 20, 22 and 43.

93 [2000] VSC 95, paras 20, quoting Gray v. Perpetual Trustee Co. Ltd., [1928] AC 391, 400.

94 [2000] NSWCA 253, paras 24 and 26.

95 Unreported judgment of Supreme Court of NSW Court of Appeal, CA 40114 of 1993, 16 May 1995, 5.

96 [2001] VSCA 228, para 18.

97 [2000] NSWCA 253, paras 24 and 26.

98 Note, the author has expressed a contrary view in Cassidy, supra note 79, at 222-245.

99 Lord Walpole v. Lord Orford, (1797) 3 Ves 402, 419-420; Ch 38, 57; Synge v. Synge, [1894] 1 QB 466, 470; Stone v. Hoskins, [1905] 1 P 194; Re Gardner, [1920] 2 Ch 523, 528-529; Re Oldham, [1925]
} 
tralian courts, it is necessary to be mindful that under the above view, to prove mutual wills a contract and, in particular, a contract not to revoke the mutual wills will need to be established. Thus it will be prudent to include contractual clauses in the will and/or accompany the will with a contract or deed.

\section{Using Mutual Wills in Conjunction With BINDING AGREEMENTS ${ }^{100}$}

Combining mutual wills with a contract or deed has to some extent been addressed above. It is nevertheless important to reiterate the benefits that stem from including contractual clauses in the wills or using a binding agreement in conjunction with mutual wills. First, this provides a means of making clear the testator's/testatrix's intention to execute mutual wills. This can be done through, for example, recitals recording the fact that "this will is a mutual will." Similarly, this can be an effective way of establishing any contractual requirement to execute mutual wills. Again this can be done through recitals that state the mutual wills "are made in pursuance of a contract." As noted above, it has been suggested that the contract include, in particular, an agreement not to revoke the wills. Establishing any contractual agreement as to the irrevocability of the wills can be achieved by expressly stating that the parties "agree that he/she will not revoke or alter his/her will during his/her lifetime without their spouse's consent."

A theme addressed above is particularly pertinent in this context. An accompanying contract/deed can make clear any obligations that the parties, particularly the survivor, have to leave a will in certain terms. In this regard it is important to clarify whether the survivor is to be constrained as to the devolution of all their property or only the property of the first to die. Again, this could be used to establish any prohibition the survivor is bound by not to unreasonably diminish his/her estate. Such a binding agreement can also make clear any obligation the recipient of an inter vivos transfer has in regard to any gifted asset, including any prohibition on its conversion or mortgaging.

As suggested above, it may be awkward, but the issue of divorce and remarrying needs to be raised with clients. Once determined, the legal consequences if the parties divorce or separate in the course of their lifetime can be set out through an accompanying binding agreement that, for example, states the agreement is automatically revoked in such a case. If an inter vivos transfer has occurred, it could also state the agreed consequences; whether that is the return of the property or its sale and the distribution of the proceeds. The agreement could deal with the legal consequences and obligations if the survivor remarries, including an agreement to

1 Ch 75, 85 and 86; Birmingham v. Renfrew, (1937) 57 CLR 666, 681; Nowell v. Palmer, (1993) 32 NSWLR 574, 579; Re Cleaver, [1981] 1 WLR 939, 946 and 947; Aslan v. Kopf, unreported judgment of Supreme Court of NSW Court of Appeal, CA 40114 of 1993, 16 May 1995, 6 and 8; Low v. Perpetual Trustees WA Ltd., (1995) 14 WAR 35, 39.

${ }^{100}$ See further the excellent paper by Ross McOmish "Mutual Wills: How and When to Use Them" presented, SA Law Society Seminar "Mutual Wills", Adelaide, 24 September 2003. 
execute a fresh will in the same terms to avoid any uncertainty through the automatic revocation of wills upon remarriage. ${ }^{101}$

Although it has been suggested above that where severance of a joint tenancy is intended this should be done in the parties' lifetime, rather than simply relying on equity's severance, the agreement could also be used to establish whether the agreement for mutual wills is intended to sever any joint tenancy.

Finally, any agreement can also serve to make clear any rights the parties have in the event of a breach. This could include provisions such as a clause confirming the right to specific performance.

\section{CONCLUSION}

Many theoretical issues pertaining to mutual wills have not been able to be canvassed in this article. ${ }^{102}$ Instead, the major focus has been a consideration of the interplay of the legal effect of mutual wills and the practical use of such wills. It is hoped that this discussion will assist legal practitioners in identifying those clients who may benefit from executing mutual wills, identifying those clients who might intend to execute mutual wills, advising clients as to the pros and cons of mutual wills and the benefits of accompanying such wills with a deed or contract.

\footnotetext{
101 The courts have held that such a revocation of the mutual will does not impact upon the trust previously created by the mutual wills agreement. Remarriage does not free property from that trust: Re Marsland, [1939] Ch 820, 826 (Eng. C.A. 1939); Re Kerr, [1948] 3 DLR 668, 679; Re Green, [1951] 1 Ch 148, 155; Clausen v. Denson, [1958] NZLR 572, 576-577; In re Dale, [1994] Ch 31, 41; Re Goodchild, [1996] 1 WLR 694, 700 and 701. Thus the trusts arising from the mutual wills agreement are not affected by the second testator's remarriage and the beneficiaries under the mutual wills agreement continue to be entitled to the benefit under such trusts. Nevertheless, any uncertainty can be avoided through a contractual clause.

102 See again CASSIDY, supra note 38.
} 